\title{
ELIMINATION OF CVB (Chrysanthemum virus B) FROM A RANGE OF CHRYSANTHEMUM VARIETIES BY APICAL MERISTEM CULTURE FOLLOWING ANTIVIRAL AGENT AND HEAT TREATMENTS
}

\author{
KURNIAWAN BUDIARTO*, BUDI MARWOTO, LIA SANJAYA, MUCHDAR \\ SOEDARJO and INDIJARTO BUDI RAHARDJO \\ Indonesian Ornamental Crops Research Institute \\ Jl. Raya Pacet-Ciheraang, PO. Box. 8 Sdl, Cianjur, West Java-Indonesia (43253)
}

Received 06 August 2010/Accepted 28 September 2011

\begin{abstract}
CVB elimination for retaining healthy protocols from infected chrysanthemum plant was investigated through combined treatment of meristem culture with synthetic antiviral ribavirin or thermotherapy under in vitro conditions. The biological materials used for the experiment constituted of six commercial varieties: Dewi Sartika, Saraswati, Yellow Fiji, White Puma, Yellow Puma and White Reagent. Tissue culture initiation was conducted through plantlet establishment using MS supplemented with IAA. Ribavirin was added in media with the concentration of $40 \mathrm{mg} / \mathrm{l}$ on cv. Dewi Sartika, Saraswati and Yellow Fiji. Parallel with this step, heat treatment with different durations (1,2, and 3 weeks) was also conducted on the plantlets on White Puma, Yellow Puma and White Reagent. Meristem culture was done following the chemo- and thermotherapy. The experiment resumed the failure of single treatment of meristem culture in eliminating CVB from the infected chrysanthemum plantlets. Under heat treatment, percentage of virus-free plantlets increased along with the duration of thermotherapy, though the survival rate of plantlets decreased in lengthened heat treatment. The best results regarding virus free plant percentage were obtained when meristem culture was applied following ribavirin or three weeks of heat treatment.
\end{abstract}

Key words: Chrysanthemum virus-B (CVB), chemotherapy, heat treatment, meristem culture, virus-free

\section{INTRODUCTION}

Chrysanthemum (Dendranthema grandiflora [Ramat.] Kitam) is one of the major cut flowers in the world. Chrysanthemum ranks the first of all cut flowers marketed

*Corresponding author : bud1arto@yahoo.com 
Apical meristem culture following antiviral agent and heat treatments - Kurniawan Budiarto et al.

every year from Indonesia (37.34\%) with the quantity of more than 66 million stalks in 2007 (Indonesian General Directorate of Horticulture 2008). Nowadays, however, chrysanthemum production has faced some constraints, and one of these was systemic disease attacks caused by viruses, viroids and phytoplasmic organisms. Up to present, Chrysanthemum Virus-B (CVB) is still one of the most common viruses found in commercial growers and have caused significant economic losses. (Marwoto et al. 2004).

Taxonomically, CVB belongs to carlavirus wide group. Genome of the virus consists of unipartite, single-stranded RNA with total genome size of $7.5 \mathrm{~kb}$ (Levay \& Zavriev 1991). The nucleocapsid (virions) are filamentous with no protein envelop and usually straight with a clear modal length of $685 \mathrm{~nm}$ (Brunt et al. 1996). Aside from chrysanthemum (Compositae), CVB was also known systemically hosted in Vicia faba (Leguminosae), Nicotiana, Petunia and Tetragonia (Megan et al. 2001). The general symptoms of the infected plant were stunted in growth, chlorotic in leaf blades, organ structure malformation and discolored petal. Degeneration in proliferation level with slower multiplication rate was also observed in the infected planlet during in vitro culture (Marwoto et al. 2004).

Efforts have been made to get healthy protocols by eliminating virus from the infected plants. Several methods such as chemo-, thermotherapy and electrical charges have been successfully conducted for virus elimination in some crops. Numerous chemicals have been tested for antiviral activity, but few were effective. The most substance is the synthetic analogue of guanosine, ribavirin (1-beta-Dribofuranosyl-1-H-1,2,4-triazole-3- carboxamide) added to the media in the range of $30-50 \mathrm{mg} / \mathrm{l}$ was affective against Potato virus X (PVX), Potato Virus Y (PVY), Potato Virus S (PVS) and Potato Virus M (PVM) in potato (Elia et al. 2008), ringspot virus in citrus (Sharma et al. 2007) and yellow leaf virus in sugarcane (Parmessur \& Saumtally 2001). Ribavirin is a member of the nucleoside anti metabolite compound that interferes with duplication of viral genetic material. Though not effective against all viruses, ribavirin is remarkable as a small molecule for its wide range of activity; including important activities against both DNA and RNA viruses (Senula et al. 2000). Ribavirin's carboxamide group can make the native nucleoside drug resemble adenosine or guanosine, depending on its rotation. For this reason, when ribavirin is incorporated into RNA, as a base analog of either adenine or guanine, it pairs equally well with either uracil or cytosine, inducing mutations in RNA-dependent replication in RNA viruses. Such hypermutation can be lethal to RNA viruses (Klein \& Livingston 2008).

Heat treatment or thermotherapy was established for virus elimination related to characteristic of some viruses which showed declination in multiplication rate especially at high temperature. This method was successfully applied in the range of $35-40{ }^{\circ} \mathrm{C}$ for producing virus-free potato plant (Converse \& Tanne 1984), alstromeria (Hakkaart \& Versluijs 1988) and apple (Wang et al. 2006). However, both chemo- and thermotherapy methods, depended on plant genotypes and viruses. Varying degree of meristem cells deaths, phytotoxic causing an increase in culture time and the need for frequent transfers into fresh media coincided with the quantity of virus-free plants obtained (Chen \& Sherwood 1991). 
The combination of both chemo- and thermotherapy with meristem culture was dedicated to encounter the technical constraints in the single application of respective techniques. These methods were also reported to be more effective for virus destruction on sweet potato, nicotiana, lemon and cucumber (Zaitlin \& Palukaitis 2000). The research was then conducted to find out the effect of ribavirin application in the media and heat treatment at different durations followed by meristem culture on the existence of CVB in infected chrysanthemum plants.

\section{MATERIALS AND METHODS}

The research was conducted at The Indonesian Ornamental Crops Research Institute (IOCRI). Six CVB infected chrysanthemum varieties i.e Dewi Sartika, Saraswati, Yellow Fiji, White Puma, Yellow Puma and White Reagent were equally divided into two parallel experiments. The first three varieties served as chemotherapy using Ribavirin, while the rest underwent the heat treatments. Fifteen cutting samples from each variety were collected and replanted in $15 \mathrm{~cm}$ pot. These were then, maintained in growth chamber for $16 \mathrm{~h}$. After 2 weeks, the plants were pinched and the new emerging lateral growths served as explants. Shoot induction was conducted by inoculating apicals into $1 / 2 \mathrm{MS}+0.5 \mathrm{mg} / \mathrm{l}$ IAA. The shoots were then subcultured into $1 / 2 \mathrm{MS}+0.1 \mathrm{mg} / \mathrm{IIAA}$ to obtain uniform plantlets.

\section{In Vitro Treatment of Ribavirin}

After three weeks incubation, the plantlets were transferred into treatments media, consisting of $1 / 2 \mathrm{MS}+0.1 \mathrm{mg} / \mathrm{l} \mathrm{IAA}$ and $1 / 2 \mathrm{MS}+0.1 \mathrm{mg} / 1 \mathrm{IAA}+40 \mathrm{mg} / \mathrm{l}$ ribavirin. Two weeks after incubation, meristematic apical of plantlets $(<0.2 \mathrm{~mm})$ were dissected using binocular microscope and transferred into MS media for shoot induction. The dissections of meristematic apical of plantlets were repeated three times from newly emerging shoots.

\section{In Vitro Heat Treatment}

One week before heat treatments, the plantlets were preconditioned in the incubator with the daily temperature of $30-35^{\circ} \mathrm{C}$. The temperature of the incubator was then increased up to $38-40{ }^{\circ} \mathrm{C}$ with the duration of 1,2 and 3 weeks. After the heat treatments, meristematic apical of plantlets was dissected and inoculated into MS media for shoot induction.

\section{ELISA Bioassay}

After transferred into regeneration media, phenotypic performance of plantlet was recorded. Randomly plantlet samples in every treatment were also selected for CVB rapid detection using direct ELISA method (Clark \& Adam 1977). An amount of $100 \mu \mathrm{l} \mathrm{CVB} \mathrm{IgG} \mathrm{(AGDIA,} \mathrm{USA)} \mathrm{was} \mathrm{mixed} \mathrm{with} \mathrm{a} \mathrm{ratio} \mathrm{of} 1: 200$ of the coating buffer $\left(\mathrm{Na}_{2} \mathrm{CO}_{3}+\mathrm{NaHCO}_{3}+\mathrm{NaN}_{3}\right)$ and overnightly incubated at the temperature of 
Apical meristem culture following antiviral agent and heat treatments - Kurniawan Budiarto et al.

$4{ }^{0} \mathrm{C}$. The microplates were then rinsed twice with PBS Tween $\left(\mathrm{NaCl}+\mathrm{KH}_{2} \mathrm{PO}_{4}+\right.$ $\mathrm{Na}_{2} \mathrm{HPO}_{4}+\mathrm{KCl}+\mathrm{NaN}_{3}+$ Tween $20+\mathrm{H}_{2} \mathrm{O}$ ) buffer of 3 minutes each. Leaf samples of $0.2 \mathrm{~g}$ were extracted and buffered with $1 \mathrm{ml}$ mixture of PBST $+0,02 \% \mathrm{PVP}(1: 5)$. The $100 \mu \mathrm{l}$ of leaf extracts were then, incubated for $2 \mathrm{~h}$ in $37^{\circ} \mathrm{C}$ and rinsed with PBS Tween buffer. After labeled with Alkaline Phosphatase enzyme, $100 \mu \mathrm{l}$ of $\operatorname{IgG} \mathrm{CVB}$ was pipetted into microplates and mixed with ECI (PBST + 0,2\% BSA) with a ratio of $1: 200$. The mixture was incubated for $2 \mathrm{~h}$ in $37{ }^{\circ} \mathrm{C}$. After $2 \mathrm{~h}$ incubation, the microplates were then rinsed with PBS Tween buffer. An amount of $100 \mu \mathrm{l}$ substrate buffer containing 4-nitrophenylphospate was placed into microplates and incubated at room temperature. After the substrate color changed into yellow, the reactions was then ceased with $25 \mu \mathrm{l} \mathrm{NaOH} 3 \mathrm{M}$. Color intensities of the substrate were measured using ELISA reader (Minireader II Dynatech) on $410 \mathrm{~nm}$ wavelength. Virus free samples were obtained when the absorbent values were three times less than that of positive control.

\section{RESULTS AND DISCUSSION}

\section{Chemotherapy by Antiviral Ribavirin}

Plantlet performances were affected by the application of antiviral ribavirin and meristem tip culture, however,there were no specific interaction between cultivars tested and antiviral treatments. The increase of regeneration capacity was significant in plant height, number of leaves and number of nodes of ribavirin-treated plantlets, when samples were supplemented with $40 \mathrm{ppm}$ ribavirin compared to untreated plants, thus hastened multiplication rate of the plantlet of all varieties tested (Table 1).

Table 1. Plantlet height, number of leaves and nodes after 30 days of subculture, and multiplication rate of chrysanthemum varieties treated with ribavirin.

\begin{tabular}{|c|c|c|c|c|c|c|c|c|}
\hline Treatments & \multicolumn{2}{|c|}{$\begin{array}{l}\text { Plantlet height*) } \\
(\mathrm{cm})\end{array}$} & \multicolumn{2}{|c|}{$\begin{array}{c}\text { Number of } \\
\text { leaves }\end{array}$} & \multicolumn{2}{|c|}{$\begin{array}{c}\text { Number of } \\
\text { nodes }\end{array}$} & \multicolumn{2}{|c|}{ Multiplication rate $\left.{ }^{*}\right)$} \\
\hline \multicolumn{9}{|c|}{ Ribavirin treatments on media } \\
\hline $\begin{array}{l}\mathrm{MS}+0.1 \mathrm{mg} / 1 \mathrm{IAA}+ \\
\text { ribavirin }\end{array}$ & 9.5 & a & 12.6 & a & 12.7 & a & 10.75 & a \\
\hline $\mathrm{MS}+0.1 \mathrm{mg} / 1 \mathrm{IAA}$ & 6.8 & $\mathrm{~b}$ & 6.4 & $\mathrm{~b}$ & 6.3 & $\mathrm{~b}$ & 7.41 & $\mathrm{~b}$ \\
\hline \multicolumn{9}{|c|}{ Chrysanthemum varieties } \\
\hline Dewi Sartika & 9.2 & a & 12.7 & a & 11.7 & a & 10.22 & a \\
\hline Saraswati & 7.5 & $a b$ & 10.2 & $\mathrm{ab}$ & 10.5 & $a b$ & 8.75 & $a b$ \\
\hline Yellow Fiji & 6.0 & $\mathrm{~b}$ & 9.1 & $\mathrm{~b}$ & 9.2 & $\mathrm{~b}$ & 6.16 & $\mathrm{~b}$ \\
\hline
\end{tabular}

*Note: Values followed by different letters in the same column differ significantly at LSD 5\%.

Faster multiplication rate of ribavirin-treated plantlets indicated that cell totipotency was retained. The most putative concerns of these phenomena were related to viricidist effect of ribavirin. The antiviral might block virus replication and although existing virus might remain in the original stem sections, the new outgrowths would be virus-free or contain only very low amounts of the virus (Simpkins et al. 1981). Ribavirin might be active in its triphosphate form, which inhibits the 5 ' capping 
of viral RNAs (Dawson \& Lozoya Saldana 1984). It inhibited virus replication at the early stage by impairing synthesis of RNA- dependent RNA polymerase and at a later stage by impairing synthesis of the coat protein (Schuster \& Huber 1991). With the absent of or low concentration viral particles, the interfering physiological orientation of embryonic derived cells were overruled to the maximum growth of genotype response.

During the experiment, no necrotic symptom used as indication of phytotoxicity was found in all varieties. Though vegetal tissues tolerance to ribavirin is genotype dependent (Sidwell et al. 2005), the chemical concentration added into the media (40 $\mathrm{mg} / \mathrm{l}$ ) was considered proportional for chrysanthemum. These might refer to the fact that with such concentration range, phytotoxic symptoms were observed in other crops during virus elimination thus, inhibited or decreased plant cellular metabolic activity when applied in higher concentration than $30 \mathrm{mg} / 1$ (Verma et al. 2005; Parmessur \& Saumtally 2001).

\section{Application of Thermotherapy}

The survival and death rates of plantlets in every duration of thermal treatments were varied among cultivars tested, though the trend was similar. During the first week of heat treatments, 24 - 36\% of treated plantlets were ceased, with cv. White Reagent showing the least number of death plantlets compared to the others. The number of death plantlets was slightly decreased in the following week, $1214 \%$ (Fig. 1). A short preconditioning incubation (one week with gradual increase at $30-35{ }^{\circ} \mathrm{C}$ ) before the thermotherapy was apparently not sufficient for the plantlet to make suitable adaptation on higher temperature of heat treatment. Though the heat tolerance of plants was indigenously specific, the mechanical adaptation of plants was timedepended on the degree of transition in regular change. The plantlet should be provided with sufficient precondition period with small and regular increase of temperature approaching the level of heat treatment to hinder high plantlet death at the early stage (Manganaris et al. 2003). Through the small gradual increase of the temperature in longer period, the plantlet could establish physiological adaptation to the temperature level of 35 to $40^{\circ} \mathrm{C}$.

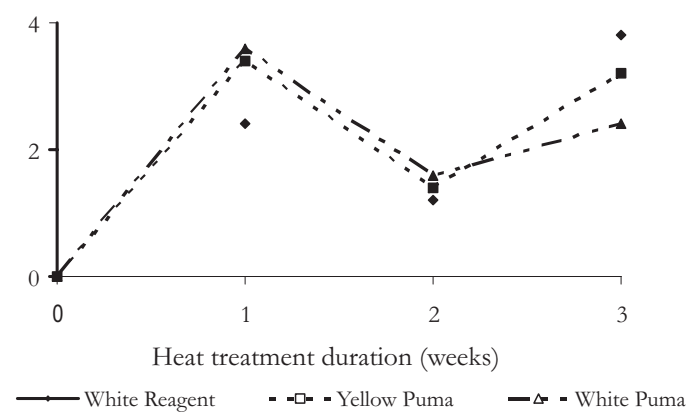

Figure 1. Plantlet death rates of three chrysanthemum cultivars after one, two and three weeks of heat treatments. 
Conversely from the first and second weeks, cv. White Reagent showed higher plantlet death rates in the third week compared to cv. White Puma and Yellow Puma (Fig. 1). This period was considered critical, since plantlet death rates of all cultivars tested were also highest in these week (24 - $38 \%$ ). Wang (2006) concluded that inside the culture flask or in vitro condition, a protected environment might lead to narrower adaptation of plantlets to the extreme conditions such as high temperature. This finding suggested that at the third week the toleration limit of chrysanthemum plantlet to heat treatments was obtained.

After heat treatments, apical meristematic tissue of individual plantlets was inoculated into shoot induction media. Period taken for bud initiation and plantlet height after three weeks transferring into regeneration media were observed different referring to the length of thermal treatments. Shortest period for bud initiation and tallest plantlets were shown by the three weeks heat treatments in all varieties tested (Table 2). Slower growth rate on plantlets treated by one and two weeks thermotherapy indicated that physiologically, the plantlets were still in their suboptimal potential. These growth retardations were predictably affected by virus particles remained in the tissues which systemic persistently interfered with plant metabolism (Marwoto et al. 2004; Bhatthacharyya et al. 1990)

Table 2. Buds initiation and plantlet height after three weeks transferring of three chrysanthemum varieties under different period of heat treatments.

\begin{tabular}{|c|c|c|c|}
\hline \multirow{3}{*}{ Cultivars } & \multicolumn{3}{|c|}{ Period of heat treatments } \\
\hline & \multicolumn{3}{|c|}{ (weeks) } \\
\hline & 1 & 2 & 3 \\
\hline \multicolumn{4}{|c|}{ Bud initiation (days) ${ }^{*}$} \\
\hline White Reagent & $63.8 \mathrm{a}$ & $64.4 \mathrm{a}$ & $49.8 \mathrm{~b}$ \\
\hline White Puma & $64.4 \mathrm{a}$ & $59.6 \mathrm{~b}$ & $48.2 \mathrm{c}$ \\
\hline Yellow Puma & $61.6 \mathrm{a}$ & $59.7 \mathrm{a}$ & $44.4 \mathrm{~b}$ \\
\hline \multicolumn{4}{|c|}{ Plantlet height alter three weeks transfering into regeneration media $\left.(\mathrm{cm})^{*}\right)$} \\
\hline White Reagent & 4,32 a & 5,11 a & $6,34 \mathrm{~b}$ \\
\hline White Puma & 4,36 a & $4.82 \mathrm{a}$ & $6.84 \mathrm{~b}$ \\
\hline Yellow Puma & $5,02 \mathrm{a}$ & $6,21 \quad b$ & $7,13 \mathrm{c}$ \\
\hline
\end{tabular}

\section{ELISA bioassay}

Virus detection using direct ELISA method was conducted to plant samples in all treatment combinations and spectro-photometerically revealed as absorbent values (Table 3). These values indicated the existence of virus particles in plant tissues. The percentage of CVB-free plantlets increased accordingly to the lengthened heat treatments and application of ribavirin within the media. Three weeks thermotherapy or supplemental antiviral followed by meristem culture successfully eliminated CVB from the infected chrysanthemum plantlets. 
The success of chemo- and thermotherapy in eliminating CVB from infected plants in our works inferred that CVB particles and their persistence was highly affected by heat treatments at $38-40{ }^{\circ} \mathrm{C}$ and antiviral application (ribavirin $40 \mathrm{mg} / \mathrm{l}$ ). The failure of single method of meristem culture for producing virus free plantlets as also presented in the absent of ribavirin treatment indicated that the isolation of meristematic sites was not sufficient to totally free the tissue from virus particles. Due to its small size, virus particles could traffic cell to cell even through branched plasmodesmata and infected the meristemal cells (Laimer 2003). Consequently, these naturally high antiviral-content tissues were also difficult to be isolated, since they were mostly microscopic and very sensitive (Brown et al. 1988). Thus, combination of thermo- or chemotherapy with meristem culture for virus elimination would be more promising, especially when mixed infection occurred or for those more persistent strains.

Table 3. CVB detection by direct ELISA and percentage of virus-free plantlets under thermo- and chemotherapy treatments.

\begin{tabular}{|c|c|c|}
\hline Treatments & Absorbance values*) & $\begin{array}{c}\text { Percentage of CVB-free plantlet }{ }^{*} \\
(\%)\end{array}$ \\
\hline \multicolumn{3}{|l|}{ Heat treatment } \\
\hline - 1 week & $0.06-0.11$ & 41.6 \\
\hline-2 weeks & $0.03-0.09$ & 72.3 \\
\hline-3 weeks & $0.02-0.07$ & 100 \\
\hline \multicolumn{3}{|c|}{ Chemotherapy using ribavirin $40 \mathrm{mg} / 1$} \\
\hline - Without ribavirin & $0.06-0.12$ & 43.6 \\
\hline - With ribavirin & $0.01-0.06$ & 100 \\
\hline Positive control & 0.22 & 0 \\
\hline Negative control & 0.01 & 100 \\
\hline
\end{tabular}

\section{CONCLUSIONS}

Under heat treatment, percentage of virus-free plantlets increased along with the duration of thermotherapy, while the survival rate of plantlets decreased in lengthened duration. The procedure of meristem culture application following ribavirin application or three weeks of heat treatment may be effective in eliminating CVB from the infected plantlets.

\section{REFERENCES}

Batthacharyya P, Dey S, Das N, Batthacharyya BC. 1990. Rapid mass propagation of Chrysanthemum morifolium by callus derived from stem and leaf explans. In Plant Cell Reports. Biotechnology Unit. Department of Chemical Engineering IIT. Kharagpur. India. p. 22 - 25.

Chen WQ, Sherwood JL. 1991. Evaluation of tip culture, thermotherapy and chemotherapy for elimination of peanut mottle virus from Arachis hypogaea. Journal of Phytopathology, 132 (3): 230 - 236.

Clark MF, Adam AN. 1977. Characteristic of the microplate method of enzyme lingked immunosorbent assay for the detection of plant viruses. Journal of Genetic Virology, 34: 475 - 483. 
Apical meristem culture following antiviral agent and heat treatments - Kurniawan Budiarto et al.

Converse RH, Tanne E. 1984. Heat therapy and stolon apex culture to eliminate mild yellow-edge virus from Hood strawberry. Phytopathology, $74: 1315$ - 1316.

Dawson WO, H Lozoya-Saldana H. 1984. Examination of the mode of action of ribavirin against Tobacco mosaic virus. Intevirology, $22: 77$ - 84 .

Elia G, Belloli C, F Cirone F. 2008. In vitro efficacy of ribavirin against canine distemper virus. Antiviral Research, $77(2): 108-113$

Hakkaart FA, Versluijs JMA. 1988. Virus elimination by meristem tip culture from a range of Alstromeria cultivars. Plt Dis. $68: 216-218$

Klein RE, Livingston CH. 2008. Eradication of potato virus X from potato by ribavirin treatment of cultured potato shoot tips. American Journal of Potato Research, 59 (8):359-365.

Laimer M. 2003. Detection and elimination of viruses and phytoplasmas from pome and stone fruit trees. Horticultural Reviews $28: 187$ - 236

Manganaris GA, Economou AS, Boubourakas IN, Katis NI. 2003. Elimination of PPV and PNRSV through thermotherapy and meristem-tip culture in nectarine. Plant Cell Reproduction, 22:195 - 200.

Marwoto BL, Sanjaya, Budiarto K, Rahardjo IB. 2004. Pengaruh antiviral dalam media kultur terhadap keberadaan chrysanthemum virus B pada 4 varietas krisan terinfeksi. Jurnal Hortikultura (edisi khusus) 14: 410 - 418.

Senula AE, Keller RJ, Leseman DE. 2000. Elimination of viruses through meristem culture and thermotherapy for the establishment of an in vitro collection of garlic (Allium sativum). Acta Horticultuae. 530:121-128.

Schuster G, Huber S. 1991. Evidence for the inhibition of Potato virus X replication at two stages dependent on the concentration of ribavirin, 5- azadihydrouracil as well as 1,5- diacetyl-5- azahydouracil. Biochemestry Phytology Pflanz, 187: 429 - 438.

Sharma S, Singh B, Rani G, Zaidi AA, Hallan V, Nagpal A, Virk GS. 2007. Production of Indian citrus ringspot virus free plants of Kinnow employing chemotherapy coupled with shoot tip grafting. Journal of Central European Agriculture, 8 (1): 1 - 8 .

Sidwell RW, Bailey KW, Wong MH, Barnard DL, Smee DF. 2005. In vitro and in vivo influenza virus-inhibitory effects of viramidine. Antiviral Research, $68(1): 10$ - 17.

Simpkins I, Walkey DGA, Neely HA. 1981. Chemical suppression of virus in cultured plant tissues. Annals of Applied Biology, 99: 161 - 169.

Parmessur Y, Saumtally A. 2001. Elimination of sugarcane yellow leaf virus and sugarcane bacilliform virus by tissue culture. J. of Food and Agricultural Research, 7 (3): 121 - 133.

Verma N, Ram R, Zaidi AA. 2005. In vitro production of prunus necrotic ringspot virus free begonias through chemo- and thermotherapy. Science Horticulture, 103: 239 - 247.

Wang I, Wang G, Tang NHR, Deng X, Zhang H. 2006. Effect of thermotherapy on elimination of apple stem grooving virus and apple chlorotic leaf spot virus for in vitro-cultured pear shoot tips. Journal of the American Society for Horticultural Science, 41(3): 1327 - 1329.

Zaitlin M, Palukaitis P. 2000. Advances in understanding plant viruses and virus diseases. Annual Review of Phytopathol, $38: 117-143$. 